\title{
The Determinants of the Choice of Alternative Financing Methods of SMEs in Bank Credit Rationing: Evidence from Cameroon
}

\author{
Benjamin Yamb ${ }^{1} \&$ Noé Ndjeck ${ }^{2}$ \\ ${ }^{1}$ Advanced School of Economics and Commerce (ESSEC), University of Douala, Cameroon \\ ${ }^{2}$ Faculty of Economics and Applied Management, University of Douala, Cameroon \\ Correspondence: Benjamin Yamb, Advanced School of Economics and Commerce, University of Douala, P.O. BOX \\ 1931, Cameroon.
}

Received: July 13, 2016

Accepted: July 25, 2016

Online Published: October 15, 2016

doi:10.5430/ijfr.v7n5p165

URL: http://dx.doi.org/10.5430/ijfr.v7n5p165

The data used in the study come from Noe NDJECK`s unpublished PHD dissertation.

\begin{abstract}
Using a method of funding is not accidental. It is based on factors of choosing a financing method. However, these factors do not all exert the same influence to lead to a type of financing, especially in the context of Small and Medium size Enterprises (SMEs) in a situation of bank credit rationing like those of Cameroon. Thus, the results obtained from a sample of 452SMEs in Douala Cameroon, through a logistic regression model, revealed that factors such as the cost of financing, the power dilution and the financial flexibility are at least three times more likely to guide the SMEs to short-term financing than to the long and medium-term ones.
\end{abstract}

Keywords: financial structure, bank credit rationing, alternative financing methods, logistic regression model, SMEs, Cameroon

\section{Introduction}

The Small Enterprise (SE) is defined as a company with a turnover ranging from 15 to100 million CFA francs, and employing 6 to 20 people. The ME (Medium size Enterprise) makes a turnover of100 million to 1 billion CFA francs, and employs 21 to 100 people (Note 1). There are several reasons why one may be interested in the Small and Medium size Enterprise (SME) in Cameroon. We can first of all see the role it plays among companies in Cameroon. Indeed, 24\% of companies in Cameroon are SMEs (National Institute of Statistics, 2010). We can then evoke the economic and social role played by SMEs in Cameroon: Kasereka Mbahweka (2009) estimates at 55\% the share of SMEs jobs in the Cameroonian labor market. He added that SMEs in this country have created $68 \%$ of jobs in the private sector in 1998. The SME in Cameroon is therefore a real core economic fabric, and is an excellent job provider (Ndong-Ntah, 2002). The VSE (Very Small Enterprise) employed 120,533 people, the SE (Small Enterprise) 67,553 and the ME (Medium size Enterprise) 49, 977in 2009 (National Institute of Statistics, 2010).

The place of the SME in the Cameroonian economy therefore justifies all the attention put in place for several decades by the public authorities to promote this category of companies. This particular attention is evidenced by the creation of umbrella organizations for SMEs, and several actions being undertaken. Finally, we can think that the SME was able to overcome the stage of a Very Small Enterprise, the dominant group of the population of the Cameroonian companies (75\% of Enterprises in Cameroon are VSE) for its ascension to a big company (only $1 \%$ of companies in Cameroon is considered as a big one, National Institute of Statistics 2010) to form a real basis for economic and social development. However, despite the political will, the SME suffers from many ills like the credit rationing, trade issues, managerial deficiencies, etc.

Foremost among the difficulties of SMEs is financing (Bekolo-EBE, 1996; Um-Ngouem 1997; Ndong Ntah, 2002). All the problems facing the SMEs in Cameroon, and to which can be added the risk which is this Enterprise segment and the lack of support structures, accentuate the bank credit rationing of this category of companies. They then use alternative financing formula, including money contribution meetings (Bekolo-Ebe 1993; Tchouassi and Ndjanyou 2002; Edding 2002; Ngongang and Wandji 2002; Wamba 2003; Assiga, 2002), which are based on some financial structure factors. 
The optimal financial structure constituting one of the major concerns of the financial theory mainly covers two aspects, namely the allocation of job resources on the one hand, and the allocation between proper funding and debts on the other. The first aspect would like that stable jobs be funded by stable resources (Hirigoyen and Jobard, 1997). However, companies live and develop themselves by financing a part of their stable jobs through short-term debts constantly renewed (Hirigoyen and Jobard, 1997). As concerns the second aspect, it favors debt in the presence of the corporate tax (Modigliani and Miller, 1963). However, this privilege is limited by the personal income tax (Miller, 1977) and bankruptcy costs that can result from excessive leverage (Albouy, 1997). Thus, the arbitration between the tax savings on corporations and bankruptcy costs leads to the optimal financial structure (Ginglinger 1997; Jensen and Meckling 1976). Therefore, at the base of these two aspects, are the determinants of the financial structure (Vernimmen 1997; Vernimmen 2010; Sulzer 1997; Belghiti, 2006) which allow making a choice between funding methods. All these determinants do not seem important in all aspects, especially for SMEs in South-Sahara, including those in Cameroon, which are characterized by the bank credit rationing, and which do not have managerial structure (Bekolo Ebe 2002; Eboué 1988; Um-Ngouem 1997; Essomba Ambassa and Um Ngouem, 2002; Joseph 2000), hence the problematic of this research on the determinants of the choice of alternative financing methods for SMEs in Cameroon in rationing bank credit situation. Therefore, the main objective of this work is to highlight the most influential determinants of the financial structure which lead to alternative financing methods for SMEs in Cameroon living in bank credit rationing. The importance of this research is twofold: firstly and theoretically speaking, this work is nothing than a continuation of the financial theory on SMEs financing, insofar as it not only gives us a clear idea on the determinants of the financial structure within the framework of SMEs, victims of the bank credit rationing and without any managerial structures, but also, it makes a typology based on the importance of each of these determinants. Secondly, this research could stand as a landmark in the orientation of SMEs on the choice of alternative financing methods, not often considered, but important in case of the bank credit rationing. Practically speaking, this work will raise awareness among SMEs on choice factors neglected by them, but which unfortunately are important. The second section of this paper presents and discusses the different works on explanatory factors on choosing a financial structure. The methodological approach used and the highlighting of some descriptive statistics are presented in the third section. The results obtained are highlighted and discussed in the fourth section, this before concluding this study.

\section{Literature Review}

The determinants of financial structure are involved in the optimal financial structure. Studies from the US and European groups to take a financial decision proved that the tax savings related to debt as well as the fear of bankruptcy costs are not essential criteria for choosing a financial structure (Vernimmen 2010). However, there is a target level of debt without which the company would be financially dependent and lose opportunities. Generally speaking, a set of factors guide the selection of a financial structure (Baker et al. 2002; Vernimmen 1997; Ginglinger, 1997). These are, among others, the concern to maintain a financial flexibility, the economic characteristics of the enterprise sector, its level of development, the sharing fixed costs / variable costs or the nature of the asset to be financed, the position of shareholders in terms of risk aversion and the desire to control, the existence of opportunities or constraints on the finance market at a given time, the financial structure of competitors.

The financial flexibility enables the company to get at any time the financial opportunities available to it, and the use of various funding sources enhances the financial flexibility (Gamba and Triantis, 2008). However, the proliferation of funding sources complicates the financial structure of the company and therefore its management, especially in case of liquidity crisis.

The industrial adventure is financed by proper funds. It is the same thing concerning a sector with higher fixed costs. Gradually as the company takes shape, indebtedness takes place and directs proper capitals towards new emerging sectors (Vernimmen, 2010). However, the high fixed costs sectors are naturally capital-intensive, and require significant investments that inevitably lead to indebtedness (Hall et al. 2004).

An asset that has little value apart from a given productive process will hardly be financed by debt. Lenders fear the fact that the asset's market value cannot cover the debt (Levasseur et al. 2000). However, one can consider additional guaranties to cover the risk.

The position of shareholders affects the financial structure. If the shareholding of the company is composed of influential shareholders (in majority or in minority), their attitude will absolutely affect the choice of funding (Jobard and Hirigoyen, 1997). Only the capital dilution in minority shareholders may reduce or eliminate this influence. In Cameroon and for illustration, shareholding is dominated by a single individual or the same family. As a result, the Cameroonian company is allergic when a capital is involved, and seems to favor debt. 
Opportunities can guide the funding method and in turn the financial structure (Baker et al. 2002).It thus appears by adventure to build a financial structure on opportunities, especially as opportunities are within economic conditions. It is noticed that the financial structures of companies in the same activities sector come together. This remark seems appropriate insofar as we are interested in the competitors' behavior. Particularly, in a rationing funding environment, companies would be characterized by the same financial structure. Other determinants of financial structure, referred to as constraints to be respected in a funding problem appear. This is according to Cohen (1997), the minimum requirement of the financial stability, the rule of repayment capacity, the rule of minimum self-financing.

The minimum financial equilibrium rule would like that stable jobs are funded by sustainable resources (Cohen, 1997). However, companies are created and they develop themselves by financing a part of their assets in short-term debts (Hirigoyen and Jobard, 1997). This rule leads to the choice between funding through stable resources and funding through circulating resources.

For the rule of repayment capacity, the amount of the financial debt should not exceed 3 or 4 times the average annual cash flow expected. Theoretically speaking, if the company does not comply with this rule, it should not claim to increase its debt. Its choice is then reduced to components of proper capitals and / or leasing (Brounen et al. 2004). However, leasing institutions carry the same risk analyzes as banks, thus reducing funding opportunities for SMEs in this way (Depallens and Jobard, 1990). Similarly, local SMEs are not accessible to the financial market, due to entry conditions that make them illegible.

In the rule of the minimum self-financing, the company must self-finance a portion (usually $30 \%$ ) of the investments for which it is seeking loans (Bar and Delahaye, 2003). However, there are companies which are created and they get into debt without providing a minimum of self-financing. This is the case of the Central Africa SMEs which are created, and which financed themselves through money contribution meetings (Mayoukou and Ossie, 1993).

Profitability, legal status, size, condition of the financial market, operational risk, ownership structure, the owner-manager or not and the number of managers, the structure of the assets, the solvency and liquidity of the assets, the distress costs, the signals, the rate of taxation and debt-related benefits, the leverage. growth potential, growth opportunities, the cost of the financing method, diluting the control power and the risk of bid, the technology risk, adapting the repayment terms to financial constraints of the company, the obtaining procedures, the required guarantees, also appear as criteria for selecting a financing method (Sulzer, 1997; Belghiti, 2006; Bar and Delahaye 2003).

However, all the criteria listed above do not seem to influence the choice of the financing methods, especially in the context of SMEs victims of the bank credit rationing, and which do not have the umbrella organizations like those in Cameroon. Thus, Modigliani and Miller (1963) bring to the foreground the tax savings related to debt, and the fear of bankruptcy costs. Extensive surveys of executives and financial directors of American (Graham and Harvey 2001) and European groups (Brounen et al. 2006) have shown that the tax savings related to debt as well as the fear of the bankruptcy costs are not the main criteria for choosing a financial structure. The financial flexibility and the impact of funding choices on credit ratings come out on top. Earnings per share is an important criterion highlighted in the decision to perform or not a capital increase (Vernimmen, 2010).

\section{Methodological Aspects and Descriptive Statistics}

\subsection{Determining the Sample's Size}

To highlight the financial structure factors explaining the choice of the types of alternative financing of short, medium or long-term, a simple random sampling was conducted. As we are unable to determine an approximate $\mathrm{P}$ value through a survey, that is to say, the proportion of SMEs interviewed as part of a preliminary study, we set at $\mathrm{P}$ to 0,5 , this value representing the worst case, that is to say, the value which gives the greatest deviation possible for the sampling distribution of $P$. In this case, the sample size required to ensure an error margin $\mathrm{E}$ (in absolute value) not exceeding $4 \%$ with a confidence level of $95 \%$ will be approximately (Note 2 ):

$$
n=\frac{Z_{\alpha / 2}^{2} P(1-P)}{E^{2}}=\frac{Z_{\alpha / 2}^{2} \times(0,5)(0,5)}{E^{2}}=\frac{(1,96)^{2}}{4(0,04)^{2}} \approx 600
$$

E: the error margin; Z: the standard normal distribution; $\bar{P}$ : the $\mathrm{P}$ estimator in the prior study. However, given the relatively limited means in our possession, only 500 SMEs in the city of Douala, in all activities sectors could be consulted among which452returned the questionnaire duly completed, which means a return rate of about $90 \%$. 


\subsection{Characteristics of the Sample}

They cover the SMEs surveyed, their promoters or main partners as well as their leaders. The attached tables summarize these different characteristics.

Indeed, it is clear from these tables that the Limited Liability Companies (LLCs) are the most numerous (56\% of the SMEs population which collaborated), followed by Individual Companies (21.9\%), Limited Companies (19, 9\%), Corporate Companies $(1.8 \%)$ and other legal forms $(0.4 \%)$. The structure of the dominant ownership capital of SMEs studied belongs to a single individual $(42.9 \%)$, then the family (31\%), friends (18.6\%), other forms of belonging (4\%), and colleagues or former colleagues $(2.7 \%)$. The dominant promoters' nationality is Cameroonian $(90.5 \%)$, followed by European $(6.9 \%)$.

SMEs are distributed in all activities' sectors. However, service provisions are the dominant sector (44.2\%). They are followed by trade (28.8\%), the manufacture of plastic packaging, the metal industry and public works (8\%), the food industry $(6.6 \%)$, the wood industry $(4.6 \%)$, the microfinance institutions $(4 \%)$, agriculture, fisheries and livestock $(1.8 \%)$, the careers' extraction $(0.90 \%)$, the clothing industry $(0.90 \%)$.

$64.6 \%$ of SMEs make a turnover between 15 and 100 million CFA francs excluding tax, $33.4 \%$ with a turnover between 100 million and 1 billion CFA Francs. $69.3 \%$ of the surveyed SMEs often make profits. $11.6 \%$ have at least 19 years of experience, $25.6 \%$ at least 15 years, $51.20 \%$ at least 06 years and $81.40 \%$ at least 04 years. $92.3 \%$ of SMEs keep accounts. However, the mere fact of holding a book is deemed to keep accounts.

Most promoters of SMEs studied in higher education (77.9\%). They have a long experience $(65.5 \%$ are over 10 years of experience), and are mostly from West Cameroon (63.5\%). 58\% of these promoters are between 30 and 50 years old. They are followed by those over 50 years old (39.8\%). Managers are academicians in majority (77.9\%). They are also experienced (50.9\% have an experience of over 10 years). They are mostly from the West region $(63.1 \%)$, and are members of money contribution meetings (65.3\%) (As promoters) as well as associations $(67,5 \%)$.

Finally, 55.1\% of SMEs surveyed consider themselves victims of qualitative rationing. 43 of the 199 SMEs which have benefited from the bank financing could not get the amount of credit requested (approximately $9.5 \%$ of SMEs who participated in the study and $21,60 \%$ of SMEs that benefited from bank financing). They are subject to a quantitative rationing.

\subsection{The Econometric Model and the Study Variables}

The main purpose of this research is to produce the effect of one or several explanatory variables on a qualitative variable with multiple responses, particularly in two responses from a logit model. This will allow us to model the probability that an event could occur, given the values of a set of descriptive variables, quantitative and / or qualitative; in other words, we will seek to predict the probability that a given SME recourses or not to a type of financing (short-term (CT), long or medium-term (LMT)), this given a set of factors that govern the choice of financing method (Sulzer 1997; Belghiti 2006 Bar and Delahaye 2003). Thus, the factors used in this work are mostly from the classical theoretical literature on corporate finance. To achieve this goal, the following logistic model was used for the occasion:

$$
\text { Type Of Funding }=1 \text { if } C T=\mu+\sum \beta_{k} X_{i}+\varepsilon_{i}
$$

\section{Otherwise}

With:

$C T=$ Short-term financing

$X_{i}$ : A vector representing all the factors governing the choice of a financing method (see Table 1 below) and $\varepsilon_{i}$ : A random perturbation that follows a white noise.

\section{Presentation of Results and Discussion}

The Counting of the SMEs by type of financing (dependent variable) as requested according to the financial structure factors (independent variable) is presented in the table below. The numbers inside the table represent the number of citations of a type of financing for a given financing method. Thus, according to the survey performed, 17 financial structure factors were identified, and they lead more to short-term funding than to long or medium-term. 
Table 1. Factors in the choice of financing methods and types of funding

Factors for choosing a financing method(FF)

\begin{tabular}{llc}
\hline 1- Financing Cost (FC); & 547 & 57 \\
\hline 2- Financial Equilibrium (FE); & 269 & 71 \\
\hline 3- Procedures for Obtaining Financing (POF) & 762 & 100 \\
\hline $\begin{array}{l}\text { 4- Adaptation of the Terms of Reimbursement to the Financial } \\
\text { Constraintsof the Company (ATRFCC) }\end{array}$ & 421 & 66 \\
\hline $\begin{array}{l}\text { 5- Guarantees Requested (GR) } \\
\text { 6- Capital Importance (CI) }\end{array}$ & 593 & 90 \\
\hline 7- Relational Proximity(RP) & 282 & 67 \\
\hline 8- Accessibility to the Source of Funding (ASF) & 608 & 84 \\
\hline 9- Financial Autonomy (FA) & 491 & 103 \\
\hline 10- Dilution of power (DP) & 127 & 26 \\
\hline 11- Financial Profitability (FP) & 200 \\
\hline 12- Nature of the Asset to Finance (NAF) & 121 & 20 \\
\hline 13- Technological Risk (TR) & 126 & 31 \\
\hline 14- Flexibility Concern (FC) & 32 \\
\hline 15- Position of Shareholders in terms of Risk Aversion (PSRA) & 80 & 12 \\
\hline $\begin{array}{l}\text { 16- Existence of Opportunities or Constraints on Financing Market at a } \\
\text { given time (EOCFM) }\end{array}$ & 14 & - \\
\hline 17- Financial Structure of Competitors (FSC) & 74 & 12 \\
\hline & 8 & 4 \\
\hline
\end{tabular}

Source: Authors, from the survey of SMEs

These 17 factors of the financial structure identified above do not exert the same influence in the choice of alternative financing methods for SMEs in bank credit rationing, as shown by the results in the table below from equation (1).

Table 2. Equation1 Estimation

\begin{tabular}{llllllll}
\hline Parameter & DF & Estimate & $\begin{array}{l}\text { Standard } \\
\text { Error }\end{array}$ & Chi- Square & $\begin{array}{l}\text { Pr }>\text { ODDS Ratio } \\
\text { ChiSq }\end{array}$ & \\
\hline Intercept & & 1 & 0.6931 & 0.6124 & 1.28 & 0.2577 & 1.9999 \\
\hline FF & FC & 1 & 1.5683 & 0.6280 & 6.24 & $0.0125^{* * *}$ & 4.7984 \\
\hline FF & FE & 1 & 0.6389 & 0.6267 & 1.04 & 0.3080 & 1.8943 \\
\hline FF & POF & 1 & 1.3376 & 0.6215 & 4.63 & $0.0314^{* *}$ & 3.8098 \\
\hline FF & ATRFCC & 1 & 1.1598 & 0.6265 & 3.43 & $0.0641^{*}$ & 3.1892 \\
\hline FF & GR & 1 & 1.1922 & 0.6227 & 3.67 & $0.0556^{* *}$ & 3.2943 \\
\hline FF & CI & 1 & 0.7441 & 0.6273 & 1.41 & 0.2355 & 2.1045 \\
\hline FF & RP & 1 & 1.2862 & 0.6233 & 4.26 & $0.0391^{* *}$ & 3.6190 \\
\hline FF & ASF & 1 & 0.8686 & 0.6219 & 1.95 & 0.1625 & 2.3835 \\
\hline
\end{tabular}




\begin{tabular}{|c|c|c|c|c|c|c|c|}
\hline $\mathrm{FF}$ & FA & 1 & 0.8929 & 0.6491 & 1.89 & 0.1689 & 2.4422 \\
\hline FF & $\overline{D P}$ & 1 & 2.1203 & 0.6807 & 9.70 & $0.0018 * * *$ & 8.3336 \\
\hline FF & FP & 1 & 1.1069 & 0.6582 & 2.83 & $0.0926^{*}$ & 3.0249 \\
\hline FF & NAF & 1 & 0.7091 & 0.6444 & 1.21 & 0.2711 & 2.0321 \\
\hline FF & TR & 1 & -0.4463 & 0.6680 & 0.45 & 0.5041 & 0.6399 \\
\hline FF & $\mathrm{FC}$ & 1 & 1.3863 & 0.6982 & 3.94 & $0.0471 * *$ & 4.0000 \\
\hline $\mathrm{FF}$ & PSRA & 1 & 21.6722 & 19208.97 & 0.00 & 0.9991 & 2582955183 \\
\hline FF & EOCFM & 1 & 1.1260 & 0.6869 & 2.69 & $0.1012 *$ & 3.0832 \\
\hline FF & FSC & 0 & 0.0000 & 0.0000 & & & 1 \\
\hline \multicolumn{8}{|c|}{ LR Statistics For Type 3 Analysis } \\
\hline \multicolumn{8}{|c|}{ The GENMOD PROCEDURE (Logit) } \\
\hline \multicolumn{3}{|c|}{ Chi- Square } & \multicolumn{2}{|c|}{ Pr $>$ ChiSq } & & & \\
\hline \multirow[t]{2}{*}{ Source } & FF & DF & & & & & \\
\hline & 16 & 100.50 & \multicolumn{2}{|c|}{$<.0001$} & & & \\
\hline
\end{tabular}

Source: Our estimates, based on data in Table1 above

*** Significant at $1 \% ; \quad * *$ significant at $5 \% ; *$ significant at $10 \%$

The analysis of the likelihood ratio test shows that the main effect factors of choosing a financing method (FF) is highly significant; in other words, the type of financing sought by the Company (Short- term or medium and long-term) will strongly depend on the choice of the financing method. However, we note that only 09 factors of the financial structure determine more significantly the recourse to short-term funding than to long and medium-term. These include: the cost of financing where our estimates reveal that the odds are about 5 times higher to lead to short-term alternative financing than to long and medium-term. The same thing goes with procedures for obtaining funding, the need for flexibility and the close relationship which are almost 4 times higher. The adaptation factors of the repayment terms to the financial constraints of the company, the required guarantees, the financial viability and the existence of opportunities or constraints on the financing market at a given time, are about 3 times more likely each, compared to the factor of power dilution which owns about 8 . These results show that the most important factors of choosing a financial structure are at least 3 times more likely to lead to alternative financing of short-term than long and medium-term.

Thus, the financing cost, the procedures for obtaining financing, the adaptation of the repayment terms to the financial constraints of the company, there quested guarantees, the relational proximity, the power dilution, the financial profitability, the flexibility concern, the existence of opportunities or constraints on the financing market at a given time, are factors that determine the financial structure of SMEs in Cameroon, which are in the bank credit rationing situation. On the contrary, factors such as the financial balance, the importance of the capital, the accessibility to the source of funding, the nature of the asset to be financed, the technological risk, the position of shareholders in terms of aversion for the risk, and the financial structure of competitors, have only an insignificant impact. Yet, these factors are also important in determining the choice of financing methods:

The financial balance which is a dear notion to the company's financing policy prevents the risk of immobilization. Indeed, it is not easy for a debtor to meet his/her payment's schedule by using the short-term resources to finance a stable employment. However, the negligence of this factor "financial balance" must surely be due to the fact that SMEs have only at their disposal the short-term resources. The importance of the capital should lead to specific financing methods. This is the case of the use of the financial market for an investment that requires significant capitals. However, SMEs in Central Africa and particularly in Cameroon have almost no access to the financial market, the access conditions constituting a barrier for them. The accessibility to the source of funding should be a very important motive for SMEs that have a very restricted financing field, especially in Central Africa. The analysis of the survey data allowed us to obtain a score of 491 responses for short-term financing against 103 for long and medium-term, this due to the accessibility factor (Table 1). Factors such as the nature of the asset to be financed, the technological risk, the 
position of shareholders in terms of risk aversion and the financial structure of competitors, seem to have no place in the context of SMEs, rationed by bank credit for the following reasons: the industrial environment for SMEs in Central Africa seems not to understand the specific technologies difficultly transferable if necessary, referring to the nature of the asset to be financed. Leasing institutions in Cameroon seem a little bit unknown on the one hand, and they are least solicited for the technological risk to influence the use of alternative financing on the other. They also adopt the same requirements like the bank (study of profitability, accounting records ...). The very small financing space of SMEs can lead them to indifference for the risk and finally, the financial structure of competitors is generally imitated; on the contrary, the state of the SMEs financing market appears to limit this possibility.

\section{Conclusion}

Factors determining the SMEs' financial structure identified in this work seem relevant in the context of these financial entities. These are, as a reminder and in order of significance: the power dilution, the financing cost, the concern for financial flexibility, obtaining financing procedures, the relational proximity, the required guarantees, adapting the repayment terms to the financial constraints of the Company, the existence of opportunities or constraints on financing market at a given time and the financial profitability. However, the concern for financial flexibility explained in this work and highlighted in major US and European groups as a factor of the choice of financial structure occupying the first position (Vernimmen, 2010, p.843) does not seem appropriate, representative or relevant to our view, insofar as loan is a rare commodity in the SMEs' environment in Cameroon. Indeed, SMEs in this environment are victims of excessive bank credit rationing (Ndjeck, 2016, p.3). They do not have access to financial market (because of their characteristics), they do not accept the capital opening to benefit from capital-risk resources (companies being for families or for individuals in majority). Similarly, leasing institutions are no longer a source of funding readily available to SMEs because they increasingly proceed to the same risk analyzes as banks, and this reduces the possibilities of SMEs' financing by this means (Depallens and Jobard 1990, p.737). It is for these reasons that SMEs fall back on alternative financing methods, essentially of short-term (including money contribution meetings, microfinance institutions, trade credit, helps towards relatives and partners' current accounts) which provide very limited resources because their custodians do not have money creation power.

We would like to draw particular attention of SMEs on the factor of financial structure, "financial balance" according to which the resources to finance a job must remain available to the company for a period at least equal to that of the financed asset. In short, stable jobs must be funded by stable resources (Cohen, 1997), even if there are companies that develop themselves by financing part of their investments through constantly renewed short-term resources (Hirigoyen and Jobard, 1997). Although SMEs' financing resources are essentially short-term, they should mobilize themselves for long and medium term financing in order to cover stable needs (long and medium term). They can for example resort to leasing institutions, venture capital firms, partners' blocked current accounts and capital increase. Thus, the golden rule of the minimum financial stability (stable jobs must be funded by stable resources) will be respected, and the risk capital of the debt avoided. However, let's not forget that leasing institutions increasingly express the same requirements as banks. Nevertheless, by reducing the information asymmetry (including the holding of a regular and honest accounting), by mitigating the managerial deficiencies (including employment of qualified personnel) and by cleaning up the economic, social and judiciary environment, the SMEs will not only become transparent, they will also present a lower risk and by extension, their funding will be improved. The requirement of the legal form of corporations to limited companies and the opening of the capital being a brake for venture capital in Cameroon, the change of mindset and function-objective of the promoter may lead to capital opening. Indeed, the function-objective of SMEs' promoters being not absolutely the search for profit (Colot and Michel, 1996), they should adopt an entrepreneurial attitude, the one that matches profit so as to enable their business to grow.

Leaders of course are rigid with the opening of capital because they fear to lose their position in the company and therefore their benefits. But in an environment where capital is scarce, capital opening could be beneficial for a company which wants to grow. However, the capital increase as the partners' current accounts is a limited source of funding in our space, SMEs having no ability to access the capital market and their performance being not good for most of them.

The criterion "accessibility of the funding source" should also be considered by SMEs because in a capital rationing context, one can only rush to available funding sources. Ignoring this criterion therefore seems controversial. Not taking into account this criterion is due to the fact that SMEs being disproportionately victims of bank credit rationing, have essentially use identical short-term resources (Ndjeck, 2016, p.369). They are their natural market, and the accessibility issue does not arise again. 
We have studied the factors related to SMEs' financing structure in general. It might be interesting to do so by SMEs' categories (small, medium enterprise), or by business sector (agricultural SME, industrial SME and service SME). This could be considered in future researches.

\section{References}

Albouy, M. (1997). Structure financière et coût du capital. Encyclopédie de gestion, sous la direction de Yves, Simon et Patrick Joffre, (Tome 3, $2^{\mathrm{e}}$ édition, article 125), Economica, Paris.

Assiga Ateba E. M. (2002). Système d'intermédiation dualiste: comportement des agents, marchés du crédit et asymétries d'information. presses universitaires de Yaoundé, mars, 27-58.

Baillargeon, G. (1989). Probabilités, statistiques et techniques de régression. Les Editions SMG., Trois Rivières QC. 631pages.

Baker, M., \& Wingler, J. (2002, February). Market timing and capital structure, Journal of Finance, 57(1).

Barreau, J., \& Delahaye, J. (2003). Gestion financière (12 édition). Dunod, Paris, 500 pages.

Bekolo Ebe B. (1993). Les tontines: Lieu d'Anticipations Financières et de réputation du pouvoir économique. l'esprit d'Entreprise, Aupelf-Uref. 10(4).

Bekolo Ebe, B. (1996). Contrats, Agence et Tontines : une application de la théorie des contrats à l'Analyse des tontines camerounaises. Mondes en développement, 94(3).

Bekolo-Ebe, B. (2002). Les défis de l'intermédiation financière en Afrique. Presses universitaires de Yaoundé, Mars, 13-25.

Belghiti, H. (2006). Les déterminants de la structure du capital: Application pour les entreprises canadiennes, Américaines de 1995 à 2005. maîtrise en administration des affaires, Université du Québec, Montréal.

Beyina Onguene E. (2008). Financement et rentabilité des PME innovantes camerounaises, thèse de doctorat ès sciences de gestion. Université Louis Pasteur, Strasbourg I, Finance.

Brounen, D., de Jong, A., \& Koedjk, K. (2004). Corporate finance in Europe: confronting theory with practice. Financial Management, 20(3), 221-258. Retrieved from https://ep.eur.nl/handle/1765/1111

Brounen, D., de Jong, A., \& Koedjk, K. (2006). Capital Structure Policies in Europe: survey evidence. Journal of Banking and Finance, 30(5), 1409-1422. http://dx.doi.org/10.1016/j.jbankfin.2005.02.010

Cohen, E. (1997). Analyse financière. In Simon Y. et Joffre P. (Eds.), Encyclopédie de Gestion (Tome 1, $2^{\mathrm{e}}$ édition, art.5). Economica, Paris.

Depallens G., \& Jobard J.P. (1990). Gestion financière de l'entreprise (10 édition). Sirey, Paris, 933 pages.

Eboue, C. (1998). Epargne Informelle et Développement en Afrique. Mondes en développement, 48(6).

Edding, C. (2002). La problématique de financement de la P.M.E. au Cameroun: une étude empirique. Presses Universitaires de Yaoundé, mars, 229-256.

Essomba Ambassa C., \& Um Ngouem M.T. (2002). Affaiblissement du rôle d'intermédiation financière dans les économies des pays d'Afrique au Sud du Sahara: un essaie d'explication. Presses Universitaires de Yaoundé, mars, 167-203.

Gamba, A., \& Triantis, A. (2008). The value of financial flexibility. Journal of Finance, 63(5). Retrieved from http://www.blackwell-synergy.com/doi/abs/10.1111/j.1540-6261.2008.01397.x

Ginglinger, E. (1997a). Marchés des capitaux et financement de l'entreprise. Encyclopédie des marchés financiers (Tome 1, $2^{\mathrm{e}}$ édition, article 44). Economica, Paris.

Ginglinger, E. (1997b). Les décisions de financements des entreprises. Nathan, 38(3).

Graham, J., \& Harvey, C. (2001). The Theory and Practice of Corporate Finance: Evidence from the Field. Journal of Financial Economics, 60(3).

Hall, G., Hutchinson, P., \& Michaelas, N. (2004, June). Determinants of the capital structure of European SMEs. Journal of Business Finance and Accounting, 31(5), 711-718. http://dx.doi.org/10.1111/j.0306-686X.2004.00554.x 
Hirigoyen, G., \& Jobard, J.P. (1997). Financement de l'entreprise: évolution récente et perspectives nouvelles. Encyclopédie de gestion, sous la direction de Yves Simon et Patrick Joffre (Tome 2, $2^{\mathrm{e}}$ édition, article 67). Economica, Paris.

Institut National de la Statistique. (2010). Recensement général des entreprises (RGE 2009). Rapport principal des résultats, septembre Yaoundé. Institut National de la Statistique.

Jensen, M., \& Meckling, W. (1976). Theory of the firm: Managerial Behaviour, agency costs and Ownership structure. Journal of Financial Economics, 3(4), 305-360.

Joseph, A. (2000). Le rationnement du crédit dans les pays en développement: le cas au Cameroun et de Madagascar. Paris, l'Harmattan. 269 pages.

Kasereka Mbahweka. (2009). Financement non bancaire des investissements des PME: une étude empirique sur des données camerounaises et congolaises (RDC) du secteur industriel. Revue camerounaise de management, (18), Juillet-décembre.

Levasseur, M., \& Quintart, A. (2000, Mars-Avril). La capacité d'endettement. Banques et Marchés, (45), 5-20.

Mayoukou, C., \& Ossie, W. (1993). Secteur financier informel et émergence de l'entrepreneuriat: application au cas du Congo. l'Esprit d'entreprise, Aupelf-Uref John Libbey Eurotext, Paris. 12(6).

Miller, M. (1977). Debt and taxes. Journal of Finance, 2(2), 261-276.

Modigliani, F., \& Miller, M.H. (1963, June). The cost of capital, corporation finance and the theory of investment. American Economic Review, 47(3), 851-866.

Ndjeck, N. (2016). Rationnement du crédit bancaire et mécanismes de financement alternatifs des PME. Thèse de doctorat non publiée, Université de Douala, Cameroun. 440 pages.

Ndong-Ntah, M.H. (2002). Financement bancaire des PME camerounaises: crise et redynamisation par les mécanismes de garantie. Presses Universitaires de Yaoundé, mars, 205-227.

Ngongang, E., \& Wandji, G. (2002). Tontines à enchères : potentialités et limites de financement au Cameroun. Presses universitaires de Yaoundé, mars, 319-345.

Sulzer, J.R. (1997). Critère de choix des investissements. In Simon Y. et Joffre P. (Eds.), Encyclopédie de gestion (tome $1,2^{\mathrm{e}}$ édition art. 41).

Tchouassi, G., \& Ndjanyou, L. (2002). Affaiblissement du rôle d'intermédiation financière dans les économies des pays d'Afrique au Sud du Sahara: un essai d'explication. Presses Universitaires de Yaoundé, mars, 59-81.

Um-Ngouem, M.T. (1997). La spécificité de l'investissement dans les PME camerounaises. Notes de recherches de l'AUPELF - UREF, 97-61.

Vernimmen, P. (1997). Politique financière de l'entreprise. In Simon Y. et Joffre P. (Eds.), Encyclopédie de Gestion (Tome 2, $2^{\mathrm{e}}$ édition, art. 125). Economica, Paris.

Vernimmen, P. (2010). Finances d'entreprises ( $8^{\mathrm{e}}$ édition). par Quirij P. et le Fury, Dalloz, Paris, 1176 pages.

Wamba, H. (2003). Analyse diachronique du système de gestion des micro-entreprises informelles en milieu urbain africain: le cas du Cameroun. Revue Gestion 2000, 36(5). Bimestriel septembre-octobre.

\section{Notes}

Note 1. Law No.2010/001 of $13^{\text {th }}$ April 2010on the Promotion of Small and Medium size Enterprises in Cameroon

Note 2. Gérald Baillargeon, "Probabilités, Statistiques et Techniques de Régression, 1989 pp 256-257, les Editions SMG

Note 3. Manufacturing plastic packaging, metal industry, construction and civil engineering, aeronautics, leather goods.

Note 4. The responses are 538in number instead of 452 because of the fact that 86 SMEs perform several activities at once. 
Appendix. Characteristics of interviewed SMEs

Distrbution of SMEs according to the Legal Nature

\begin{tabular}{|c|c|}
\hline Form & Number \\
\hline $\begin{array}{l}\text { Limited Liability Company } \\
\text { (LIC) }\end{array}$ & $253(56 \%)$ \\
\hline Limited Company (LC) & $90(19.9 \%)$ \\
\hline SNC & $8(1.8 \%)$ \\
\hline Individual Companies & $99(21.9 \%)$ \\
\hline Other Forms & $2(0.4 \%)$ \\
\hline Total & $4 \leqslant 2(100 \%)$ \\
\hline
\end{tabular}

Distribution of SMEs by the Capital Structure

\begin{tabular}{lr}
\hline \multicolumn{1}{c}{ Capital Property } & \multicolumn{1}{c}{ Number } \\
\hline A Single Individual & $194(42.9 \%)$ \\
\hline Non-responders & $4(0.9 \%)$ \\
\hline The Same Family & $140(31 \%)$ \\
\hline Friends & $84(18.6 \%)$ \\
\hline Colleagues or Former Colleagues & $12(2.7 \%)$ \\
\hline Other Forms of Membership & $18(4 \%)$ \\
\hline \multicolumn{2}{c}{ Total } \\
\hline
\end{tabular}

Distribution of SMEs according to the Promoters' Nationality

\begin{tabular}{lr}
\hline \multicolumn{1}{c}{ Nationality } & \multicolumn{1}{c}{ Number } \\
\hline Cameroomian & \multicolumn{1}{c}{$409(90.5 \%)$} \\
\hline European & $31(6.9 \%)$ \\
\hline Others & $10(2.6 \%)$ \\
\hline Non-responders & $2(0.4 \%)$ \\
\hline \multicolumn{1}{c}{ Total } & $\mathbf{4 5 2 ( 1 0 0 \% )}$ \\
\hline
\end{tabular}

Distribution of SMEs by Activities' Sectors

\begin{tabular}{lr}
\hline \multicolumn{1}{c}{ Activities' Sectors } & \multicolumn{1}{c}{ Number } \\
\hline Road Transportation & $27(8 \%)$ \\
\hline Service Provisions & $200(44.2 \%)$ \\
\hline Trade & $130(28.8 \%)$ \\
\hline Food Industry & $30(6.6 \%)$ \\
\hline Wood Industry & $21(4.6 \%)$ \\
\hline Micro-finance Institutions & $18(4 \%)$ \\
\hline Agriculture, Fisheries, Livestock & $8(1.1 \%)$ \\
\hline Careers Extraction & $4(0.9 \%)$ \\
\hline Clothing Industry & $4(0.9 \%)$ \\
\hline Other Activities (Note 3) & $96(21.2 \%)$ \\
\hline \multicolumn{1}{c}{ Total } & $\mathbf{5 3 8 ( N o t e ~} 4)$ \\
\hline
\end{tabular}

Distribution of SMEs according to the Number of Employees

\begin{tabular}{lr}
\hline \multicolumn{1}{c}{ Persons Employed } & \multicolumn{1}{c}{ Number } \\
\hline 6 to 20 & $263(58.2 \%)$ \\
\hline 21 to 100 & $187(41.3 \%)$ \\
\hline Non-responders & $2(0.5 \%)$ \\
\hline Total & $\mathbf{4 5 2}(100 \%)$ \\
\hline
\end{tabular}

Distribution of SMEs according to the Tumover

\begin{tabular}{lr}
\hline \multicolumn{1}{c}{ Turnorer } & \multicolumn{1}{c}{ Number } \\
\hline 15 to100 million & $292(64.6 \%)$ \\
\hline 100 million to 1 billion & $152(33.4 \%)$ \\
\hline Non-responders & $8(2 \%)$ \\
\hline Total & $\mathbf{5 2}(100 \%)$ \\
\hline
\end{tabular}

Distribution of SMEs according to Results Achieved

\begin{tabular}{|c|c|}
\hline Gains obtained & Number \\
\hline Profits more often obtained & $313(69.3 \%)$ \\
\hline Others & $133(30.7 \%)$ \\
\hline Non-responders & $6(1.3 \%)$ \\
\hline Total & $452(100 \%)$ \\
\hline \multicolumn{2}{|c|}{ Distribution of SMEs according to Accounting } \\
\hline Accounting & Number \\
\hline Accounting & $417(92.3 \%)$ \\
\hline No Accounting & $33(7.3 \%)$ \\
\hline Non-responders & $2(0.4 \%)$ \\
\hline Total & $452(100 \%)$ \\
\hline
\end{tabular}

Qualitative Distribution of Bank Credit for SMEs According to Rationing

\begin{tabular}{lr}
\hline $\begin{array}{c}\text { Qualitative Bank Credit } \\
\text { Rationing }\end{array}$ & \multicolumn{1}{c}{ Number } \\
\hline Number rationed & $249(55.1 \%)$ \\
\hline Number non-rationed & $199(44 \%)$ \\
\hline Non-responders & $4(0.9 \%)$ \\
\hline \multicolumn{1}{c}{ Total } & $\mathbf{4 5 2 ( 1 0 0 \% )}$ \\
\hline
\end{tabular}

Distribution of SMEs according to the quantity rationing of bank credit

\begin{tabular}{cc}
\hline $\begin{array}{c}\text { Quantity Rationing of } \\
\text { Bank Credit }\end{array}$ & Number \\
\hline Number rationed & $43(21.6 \%)$ \\
\hline Number non-rationed & $156(78.4 \%)$ \\
\hline Total & $199(100 \%)$ \\
\hline
\end{tabular}


Distribution of SMEs Promoters according to their Membership to the Money Contibution Meeting

\begin{tabular}{|c|c|}
\hline $\begin{array}{c}\text { Members of the Money Contribution } \\
\text { Meeting }\end{array}$ & Number \\
\hline Members promoters & $306(67.7 \%)$ \\
\hline Non-members Promoters & $146(32.3 \%)$ \\
\hline Total & $452(100 \%)$ \\
\hline \multicolumn{2}{|c|}{$\begin{array}{l}\text { Distribution of SMEs Promoters according to the } \\
\text { Association Membership }\end{array}$} \\
\hline Association Member & Number \\
\hline Promoters members & $313(69.2 \%)$ \\
\hline Promoters non-members & $139(30.8 \%)$ \\
\hline Total & $452(100 \%)$ \\
\hline
\end{tabular}

Distribution of SMEs Promoters according to their Training

\begin{tabular}{lr}
\hline \multicolumn{1}{c}{ Studies } & \multicolumn{1}{c}{ Number } \\
\hline Primary & $6(1.3 \%)$ \\
\hline Secondary & $86(19 \%)$ \\
\hline University & $352(77.9 \%)$ \\
\hline Professional Training & $6(1.3 \%)$ \\
\hline Non-responders & $2(0.4 \%)$ \\
\hline \multicolumn{1}{c}{ Total } & $\mathbf{4 5 2 ( 1 0 0 \% )}$ \\
\hline
\end{tabular}

Distribution of SMEs according to the Professional Experience of Promoters

\begin{tabular}{lr}
\hline \multicolumn{1}{c}{ Age Groups Erperience } & \multicolumn{1}{c}{ Number } \\
\hline Below 5 years old & $32(7.1 \%)$ \\
\hline From 5 to 10 years old & $120(26.5 \%)$ \\
\hline Above 10 years old & $296(65.5 \%)$ \\
\hline Non-responders & $4(0.9 \%)$ \\
\hline \multicolumn{1}{c}{ Total } & $\mathbf{4 5 2 ( 1 0 0 \% )}$ \\
\hline
\end{tabular}

Distribution of SMEs according to the Promoters Origins

\begin{tabular}{|c|c|}
\hline Promoters'0rigins & Number \\
\hline West- Cameroon & $287(63.5 \%)$ \\
\hline Center-Cameroon & $61(13.5 \%)$ \\
\hline South-Cameroon & $4(0.9 \%)$ \\
\hline North-Cameroun & $4(0.9 \%)$ \\
\hline Littoral-Cameroon & $43(9.5 \%)$ \\
\hline Others & $51(11.3 \%)$ \\
\hline Non-responders & $2(0.45 \%)$ \\
\hline Total & $452(100 \%)$ \\
\hline
\end{tabular}

Distribution of SMEs according to Promoters' Age

\begin{tabular}{lr}
\hline \multicolumn{1}{c}{ Age Groups } & \multicolumn{1}{c}{ Number } \\
\hline Below 30 years old & $8(81.8 \%)$ \\
\hline From 30 to 50 years old & $262(58 \%)$ \\
\hline Above 50 years old & $180(39.8 \%)$ \\
\hline Non-responders & $2(0.4 \%)$ \\
\hline Total & $452(100 \%)$ \\
\hline
\end{tabular}

Distribution of SMEs according to the Managers' Age

\begin{tabular}{lr}
\hline \multicolumn{1}{c}{ Age groups } & \multicolumn{1}{c}{ Number } \\
\hline Below 30 years old & $18(4 \%)$ \\
\hline From 30 to 50 years & $294(65 \%)$ \\
\hline Above 50 years & $136(30.1 \%)$ \\
\hline Non-responders & $4(0.9 \%)$ \\
\hline \multicolumn{1}{c}{ Total } & $+52(100 \%)$ \\
\hline
\end{tabular}

Distribution of SMEs Managers according to their Membership in the Money Contribution Meeting

\begin{tabular}{|c|c|}
\hline $\begin{array}{l}\text { Member of the Money Contribution } \\
\text { Meeting }\end{array}$ & Number \\
\hline $\begin{array}{l}\text { Leaders members to the Money } \\
\text { Contribution Meeting }\end{array}$ & $295(65.3 \%)$ \\
\hline $\begin{array}{l}\text { Leaders non-member to the Money } \\
\text { Contribution Meeting }\end{array}$ & $153(34.3 \%)$ \\
\hline Non-responders & $2(0.4 \%)$ \\
\hline Total & $452(100 \%)$ \\
\hline
\end{tabular}

Distribution of SMEs Managers according to the Association Membership

\begin{tabular}{|c|c|}
\hline Association Member & Number \\
\hline Leaders members & $305(67.5 \%)$ \\
\hline Leaders non-members & $145(32.1 \%)$ \\
\hline Non-responders & $2(0.4)$ \\
\hline Total & $452(100 \%)$ \\
\hline
\end{tabular}

